\title{
Surge dynamics in the Nathorstbreen glacier system, Svalbard
}

\author{
M. Sund ${ }^{1,2}$, T. R. Lauknes ${ }^{3}$, and T. Eiken ${ }^{4}$ \\ ${ }^{1}$ Hydrology department, Norwegian Water Resources and Energy Directorate, P.O. Box 5091 Majorstuen 0301 Oslo, Norway \\ ${ }^{2}$ University Centre in Svalbard, P.O. Box 156, 9171 Longyearbyen, Norway \\ ${ }^{3}$ Norut, P.O. Box 6434 Forskningsparken, 9294 Troms $\emptyset$, Norway \\ ${ }^{4}$ Department of Geosciences, University of Oslo, P.O. Box 1047 Blindern, 0316 Oslo, Norway
}

Correspondence to: M. Sund (sund.monica@gmail.com)

Received: 5 September 2013 - Published in The Cryosphere Discuss.: 8 October 2013

Revised: 24 February 2014 - Accepted: 26 February 2014 - Published: 11 April 2014

\begin{abstract}
Nathorstbreen glacier system (NGS) recently experienced the largest surge in Svalbard since 1936, and this was examined using spatial and temporal observations from DEM differencing, time series of surface velocities from satellite synthetic aperture radar (SAR) and other sources. The upper basins with maximum accumulation during quiescence corresponded to regions of initial lowering. Initial speed-up exceeded quiescent velocities by a factor of several tens. This suggests that polythermal glacier surges are initiated in the temperate area before mass is displaced downglacier. Subsequent downglacier mass displacement coincided with areas where glacier velocity increased by a factor of 100-200 times (stage 2). After more than 5 years, the joint NGS terminus advanced abruptly into the fjord during winter, increasing velocities even more. The advance was followed by up-glacier propagation of crevasses, indicating the middle and subsequently the upper part of the glaciers reacting to the mass displacement. NGS advanced $\sim 15 \mathrm{~km}$, while another $\sim 3 \mathrm{~km}$ length was lost due to calving. Surface lowering of $\sim 50 \mathrm{~m}$ was observed in some up-glacier areas, and in 5 years the total glacier area increased by $20 \%$. Maximum measured flow rates were at least $25 \mathrm{~m} \mathrm{~d}^{-1}, 2500$ times quiescent velocity, while average velocities were about $10 \mathrm{~m} \mathrm{~d}^{-1}$. The surges of Zawadzkibreen cycle with ca. 70-year periods.
\end{abstract}

\section{Introduction}

Svalbard is one of the areas with a dense population of surge-type glaciers. However, relatively few glacier surges here have been studied in detail, especially covering both the entire quiescent and surge phase (Sund and Eiken, 2004;
Murray et al., 2012). The mechanism behind glacier surging has been studied for several decades, but the exact cause still remains unknown. Remote sensing techniques, however, have improved the temporal and spatial data resolution and give new perspectives on glacier dynamics. In this paper we mainly used satellite remote sensing data acquired between 1992 and 2012 to investigate the surge dynamics of the different glaciers in the Nathorstbreen glacier system (NGS), during the largest surge on Svalbard since 1936.

Glacier surges occur as quasi-cyclic rapid velocity accelerations of 10-1000 times quiescent phase velocity. Fast flow is associated with a large basal motion component (e.g. Clarke, 1987). The events are triggered by internal rather than external dynamic processes. In the course of the surges, large masses of ice are transferred from higher to lower parts of the glacier. During the quiescent-phase build-up, the glacier's surface gradient increases. Surges are found both in land- and tidewater-terminating glaciers as well as temperate and polythermal ones. (Meier and Post, 1969; Dolgoushin and Osipova, 1975; Clarke et al., 1984; Cuffey and Patterson, 2010). Based on studies from the temperate Variegated Glacier, Alaska, a hydraulic mechanism was proposed where surges are explained by switches between an efficient tunnel-based basal drainage system and slow linked-cavity system (Kamb et al., 1985; Kamb, 1987). Some surges display an abrupt speed-up and slow-down (days to weeks), while other glaciers go through slower (years-long) accelerations and decelerations. Differences in observed surge characteristics and dynamics have also led to a suggestion of at least two separate surge mechanisms between polythermal and temperate glaciers (Murray et al., 2003a). Surges in polythermal glaciers were explained by changes in basal thermal 


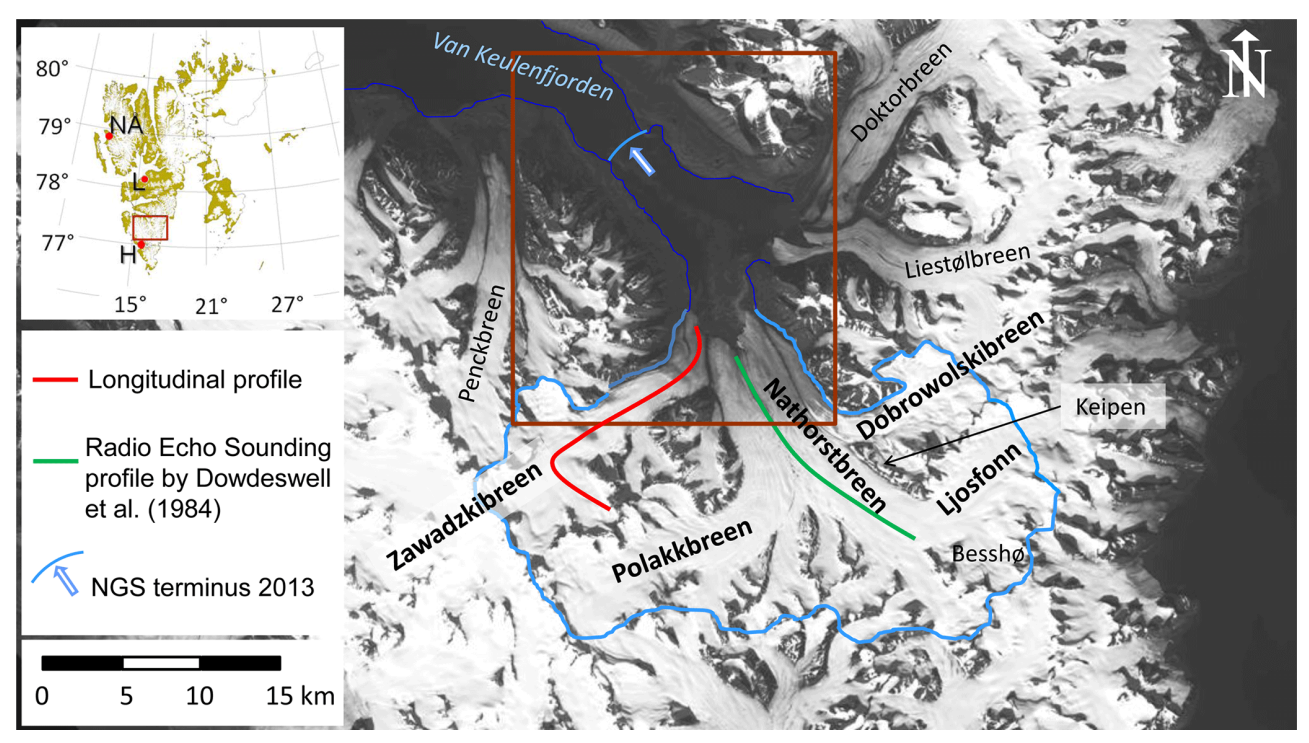

Fig. 1. Inset map: main islands of Svalbard, with meteorological stations Ny-Ålesund (NÅ), Svalbard Lufthavn - Longyearbyen (L), and Hornsund (H). Nathorstbreen glacier system (blue outline) drains into Van Keulenfjorden. The red outline refers to Fig. 7. Background image: 1 September 2008 is from the Système Probatoire pour l'Observation de la Terre (SPOT) Stereoscopic survey of Polar Ice: Reference Images and Topographies $\left(\right.$ SPIRIT $^{\odot}$ ) programme, Centre National d'Etudes, France (2007), and SPOT image 2008, all rights reserved.

regime that are controlled by a thermal mechanism (Murray et al., 2000; Fowler et al., 2001), while the temperate surges were explained by a hydraulic mechanism (Kamb, 1987). Detailed spatial measurements of surge onset are rare due to the difficulty in predicting them. The main emphasis of many investigations has been on the visible part of the surges. For example, several studies have observed surge initiation during winter (e.g. Raymond and Harrison, 1985; Echelmeyer et al., 1987; Osipova and Tsvekov, 1991; Eisen et al., 2005; Pritchard et al., 2005). Up-glacier propagation of surges from their suggested trigger area has been inferred from up-glacier propagation of crevasses (Raymond, 1987; Hodgkins and Dowdeswell, 1994). While mainly focusing on relative changes in surface elevation rather than traditional surge characteristics, Sund et al. (2009) found several glaciers showing signs of early-stage surges before they had reached the visible or advancing stage, and suggested three stages for the surge development during the active phase. Stage 1 is characterised by a moderate surface lowering in the upper part of the glacier and is followed by a relative thickening further downglacier in stage 2 . Stage 3 corresponds to the period of well-known surge characteristics in which large parts of the glacier are affected, heavy crevassing is present and the front sometimes advances.

Due to the remote location and large spatial extent of NGS, satellite remote sensing methods are well suited to estimate glacier velocities. In particular, active microwave instruments such as synthetic aperture radar (SAR) are able to penetrate clouds as well as making observations during the polar night. The surge of NGS makes it possible to study several glacier tributaries subject to relatively similar climate conditions. This study elaborates on surge initiation as well as propagation in the studied glaciers of NGS and provides a new interpretation of surge behaviour. We examined the evolution of the temporal and spatial distribution of velocities combined with surface elevation changes between 1936 and 2008. The main focus is on glacier dynamics prior to and during the transition to the visible, heavily crevassed advancing stage. The characteristics of the individual glacier surges are also investigated.

\section{Background}

The NGS is located in southern Svalbard and covered an area of $\sim 430 \mathrm{~km}^{2}$ prior to the current surge. The glaciers flow from $\sim 700 \mathrm{~m}$ a.s.l. in the eastern basins and extend $20-30 \mathrm{~km}$ westward, entering Van Keulenfjorden at sea level. No previous surges have been observed, yet several historical sources point to such events. Liestøl $(1973,1977)$ inferred a surge with a maximum extent around 1870 extending past the narrowing in the fjord. The Dunér-Nordenskiöld map from 1861 to 1864 (Hamberg, 1905) indicates that by then the terminus of the NGS as well as Liestølbreen (Fig. 1) was around $12 \mathrm{~km}$ further back in the fjord than during the advance maximum (Harland, 1997). On Hamberg's map (1905) from 1898 an advance had occurred and a calving bay at the terminus indicates a beginning retreat. Folded moraines were also present, and Gripp (1927) took these as indications of glacier advance in these basins. Such formations were later viewed as one of the main characteristic of previous surges (Meier and Post, 1969). Even older maps also show indications of 
front fluctuations. Although they are not precise, several of the maps back to 1634 presented in Conway (1906) show a narrow passage similar to the current narrow part of the fjord, indicating smaller glacier extent than at present. The maps, however, do not give any information on which of the glaciers at the head of Van Keulenfjorden were involved in the advances and retreats.

Between 1898 and 2002 the joint termini of Liestølbreen and Nathorstbreen retreated $\sim 17.5 \mathrm{~km}$. The retreat rate was greatest around 1958-1961 and corresponded well to locations of maximum water depth (Carlsen, 2004). Retreat is common in Svalbard surge-type tidewater glaciers during their quiescent phase, when ice fluxes are low. The joint termini of Zawadzkibreen (previously spelled Zawadskibreen), Polakkbreen and Nathorstbreen (Fig. 1) started to advance into Van Keulenfjorden during winter 2008-2009, while the first indications of mass displacement were already visible in 2003 (Sund et al., 2009).

\section{Data and methods}

\subsection{Satellite data and aerial photos}

NGS is located along the commercial flight route between Longyearbyen and Troms $\varnothing$, enabling acquisition of detailed images from the air on clear-weather days. Several hundred images taken by different photographers from aircraft and in the field during the period 2007-2013 were used in this study, and older photographs supplemented this data set. Recent aerial photos from the Norwegian Polar Institute (NPI) ( $0.6 \mathrm{~m}$ resolution) were also used for comparison.

In order to detect the front position, we used all available optical satellite images from the Moderate Resolution Imaging Spectroradiometer (MODIS) (250 m resolution), as well as radar satellite data from the European Space Agency (ESA) Envisat Advanced Synthetic Aperture Radar (ASAR) in wide-swath mode. The northern location of the studied NGS and the polar orbit of the Envisat satellite allows for daily coverage.

Our glacier velocity analysis was based on several satellite SAR sensors. From ESA we used ERS-1 data from the 3 day ice-phase mission in January-March 1992, as well as Envisat ASAR data from 2002 to 2010. In addition we used Radarsat-2 data from 2010 to 2012 . The SAR sensors operate at a wavelength $5.6 \mathrm{~cm}$, with a repeat cycle of 24-35 days. Some of the satellite images were used for estimates of glacier area lost due to calving, although images from commercial aircraft were used as the main basis for calving estimates.

\subsection{Digital elevation models}

New and old maps (Hamberg, 1905; NPI main map series of Svalbard, 1:100 000 old and new edition, based on aerial photographs from 1936 and 1990) were studied. We used surface digital elevation model (DEM) differencing to derive geometrical elevation changes. The 1936 DEM was generated from NPI map contour lines based on oblique aerial photographs from 1936 and has a grid size of $100 \mathrm{~m}$. However, some of the undulations were probably exaggerated as a result of the DEM generation method. In the case of Zawadzkibreen and Polakkbreen the 1936 photographs were taken in the up-glacier direction, which makes the elevation accuracy lowest in the upper part, where it is estimated to be $\sim 15 \mathrm{~m}$ root mean square (rms). The 1990 DEM was photogrammetrically compiled by the NPI from vertical aerial photographs, and has a grid size of $20 \mathrm{~m}$. The estimated vertical accuracy of the 1990 DEM is $\sim 2 \mathrm{~m} \mathrm{rms}$ in flat areas, decreasing to $\sim 6 \mathrm{~m} \mathrm{rms}$ on steep slopes. The photo/DEM coverage is missing in the upper part of Dobrowolskibreen and Ljosfonn (Fig. 1). Advanced Spaceborne Thermal Emission and Reflection Radiometer (ASTER) data from 2003, with a spatial resolution of $15 \mathrm{~m}$, were used to generate a DEM following the same concept as in Sund et al. (2009). ASTERderived elevations are not sufficient to detect changes in topographic details. For the purpose of this study, however, the mass displacement pattern is the important factor. For our ASTER-derived DEMs we estimated the vertical accuracy for an individual elevation point to be better than $15 \mathrm{~m}$ rms for conditions of sufficient optical contrast in the images used, as supported by an extensive test study in eastern Svalbard (Kääb, 2008). The 2008 SPOT 5 HRS (from Satellite Pour l'Observation de la Terre) DEMs have $40 \mathrm{~m}$ resolution and vertical accuracy of $10 \mathrm{~m}$ with $90 \%$ confidence on surface slopes less than $20 \%$ (Korona et al., 2009), which applies to most of the glacier surfaces studied here. For topography in the fjord, bathymetric contour lines collected in 1999 and 2001 by the Norwegian Hydrographic Service (Carlsen, 2004) were digitised and extrapolated to the shore line to fill data gaps.

\subsection{Velocity measurements}

We applied both SAR interferometry (InSAR) (Goldstein et al., 1993; Joughin et al., 1996) as well as the SAR offsettracking method (Strozzi et al., 2002; Rignot et al., 2011; Paul et al., 2013) in order to estimate glacier velocities. The InSAR method measures displacement in the radar line-ofsight (LOS) direction, with a precision of the order of millimetres to centimetres, while offset tracking provides information about azimuth and range surface displacements, with a precision of the order of decimetres to metres.

Ortho-rectified images, orthophotos, compiled from images were used for crevasse tracking for velocity measurements, compiling of front positions, and calving estimates. 
Velocity calculations as well as estimates of calving were made following the method of Eiken and Sund (2012). Accuracy of orthophotos is estimated to be $50 \mathrm{~m}$ (rms) for welldefined details, and better than $100 \mathrm{~m}$ for interpreted features such as front positions.

\subsection{InSAR processing of ERS-1 SAR data}

Based on two ERS-1 SAR scenes (ascending track 37) from the ice-phase mission (3-day revisit time) from 24 January 1992 and 27 January 1992, we produced a 3-day differential interferogram. The radar looks to the right (approximately east) with an angle of $\sim 23.5^{\circ}$ from the vertical, with a spatial baseline of $37 \mathrm{~m}$. A spatial multilooking of 2 looks in range and 8 in azimuth provided pixels with a ground resolution of $\sim 40 \mathrm{~m} \times 30 \mathrm{~m}$. The $1990 \mathrm{DEM}$ was used to remove the topographic phase contribution. The interferogram was unwrapped using SNAPHU software (Chen and Zebker, 2001). An area with exposed bedrock was used to calibrate the InSAR phase. The final unwrapped results were then geocoded to an output grid of $20 \mathrm{~m} \times 20 \mathrm{~m}$. Low-coherence areas as well as non-glaciated areas were masked out. We stress that the InSAR method for surface displacement has certain limitations. First, the radar measures displacement in the LOS direction only, and sensitivity is thus zero in cases where the actual surface displacement vector is perpendicular to the LOS. In order to compare surface displacement velocities from different methods, we assumed surface-parallel flow and projected the InSAR LOS velocities onto the downslope direction using a profile along the glacier.

\subsection{Offset-tracking processing of SAR data}

We used a cross-correlation-based method to estimate range and azimuth offsets between pairs of SAR data acquired in the same geometry (Paul et al., 2013). The input SAR data from each sensor were coregistered to a reference geometry, and the range and azimuth shifts were estimated by searching for the maximum of the two-dimensional correlation function estimated by using rectangular matching window sizes uniformly distributed over the image frame. The quality of the estimates is provided by the signal-to-noise ratio (SNR) of the measurement. We masked out the points with low SNR and removed outliers by applying a median filter.

The output of the offset-tracking algorithm is geocoded velocity fields, measured in the plane spanned by the range and azimuth vectors. As with InSAR the surface-parallel flow approximation was used to project the range and azimuth velocities onto the downslope direction, using a profile along the glacier.

\section{Results}

In order to investigate the surge dynamics of the individual glaciers, the spatial and temporal observations were evaluated according to the different glacier branches. All coordinates in figures are in the UTM 33X coordinate system. Processing of all SAR data was done with the Norut GSAR software (Larsen et al., 2005).

\subsection{Pre-advance observations (mainly surge stage 1 and 2)}

On the map from 1898 (Hamberg, 1905) considerably larger portions of the moraine on the northern side of the fjord are exposed, indicating more melt than on the southern side. Together with the looped moraine pattern this indicates that Liestølbreen surged before NGS. Three sets of folded moraines on NGS appear to originate from Zawadzkibreen and Polakkbreen, indicating that several of the glaciers in NGS also participated in the ca. 1870 advance, with Zawadzkibreen as the final glacier to advance. However, the approximately straight medial moraines between Zawadzkibreen and Nathorstbreen suggested a relatively simultaneous advance, as occurred during the last surge. In spite of a possibly smaller advance than during the recent surge, the glacier systems occupied a larger part of the fjord width at that time. The NGS retreat between 2002 and 2008 was $\sim 200 \mathrm{~m}$, or $33 \mathrm{~m} \mathrm{a}^{-1}$, except for an initial, small advance in parts of Dobrowolskibreen. It is also worth mentioning that by August 2013 the adjacent glacier Penckbreen, west of Zawadzkibreen (Fig. 1), had developed crevassing along a large part of its length due to surge activity.

\subsubsection{Dobrowolskibreen}

Dobrowolskibreen was the first glacier in the system to surge (Sund et al., 2009), resulting in activation of the stagnant marginal ice at the northern side of the NGS terminus (Sund and Eiken, 2010). The ERS-1-InSAR 3-day interferograms from January 1992 indicated a nucleus of increased speed just up-glacier of the confluence (Fig. 2a). In 2000, velocities near the terminus were more than $0.5 \mathrm{~m} \mathrm{~d}^{-1}$ (Fig. 2b).

In 2003, when the Dobrowolskibreen was in stage 2 of a surge with thinning at higher elevations and thickening close to the terminus (Sund et al., 2009), large, transverse crevasses were seen in the upper keyhole-shaped basin on ASTER. Comparison of images from ASTER (between 2005 and 2006) and from aircraft showed that ice along the northern margin was activated all the way to the terminus by 2006. However, detailed observations were necessary to determine the slight advance over several years prior to 2009 appearing in the northern third of the NGS terminus. By late 2007, velocities had increased (Fig. 2c) in the lower reaches of Dobrowolskibreen, where ice had been thickening (Fig. 3c) and where the terminus was now advancing and calving. 

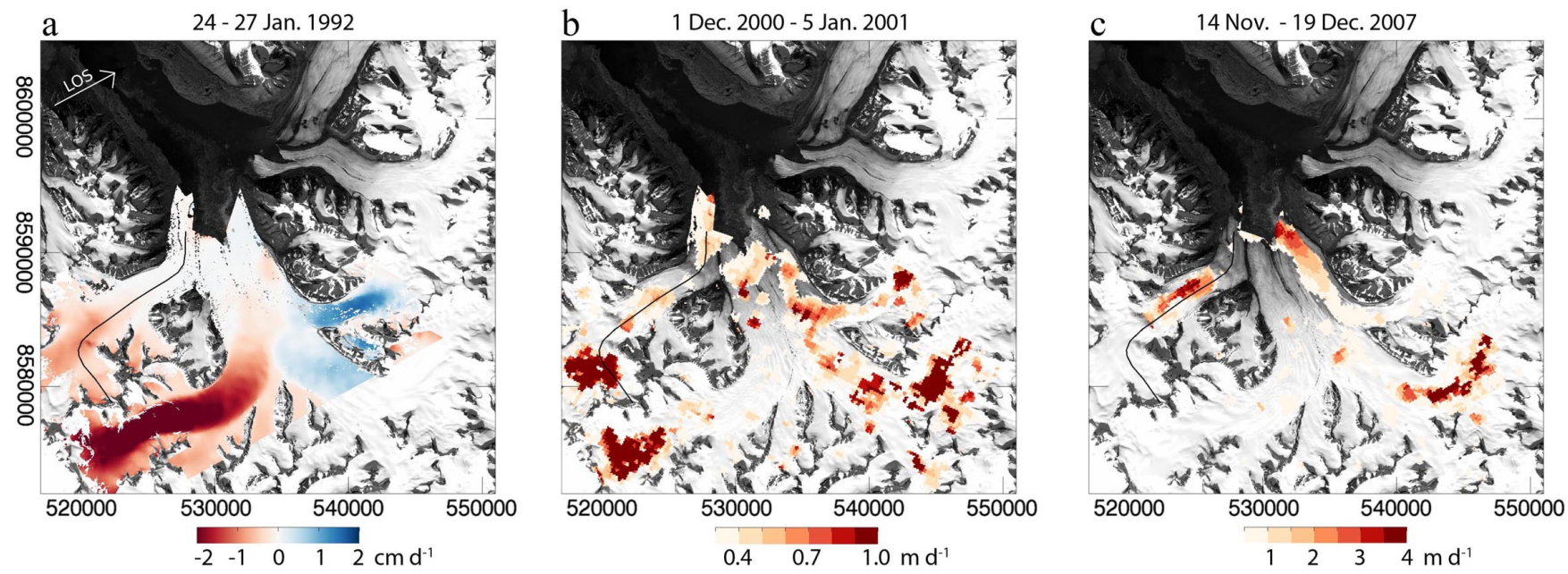

Fig. 2. Temporal and spatial velocity distribution in the Nathorstbreen glacier system. Surface elevations and velocities along the profile shown on Zawadzkibreen, the glacier to the left, are given in Fig. 4. (a) ERS-1 3-day InSAR velocity in radar LOS. Positive values indicate motion towards the radar and negative values indicate motion away from the radar. The arrow indicates the radar LOS. (b) ERS-2 35-day offset tracking. (c) Envisat ASAR 35-day offset tracking. Note how increased velocities propagate from higher to lower parts of the glaciers. Colour scales are enhanced to display velocity variations. Velocities higher than the maximum on the scale are found in limited areas. Background image by SPOT SPIRIT $2008^{\circledR}$.
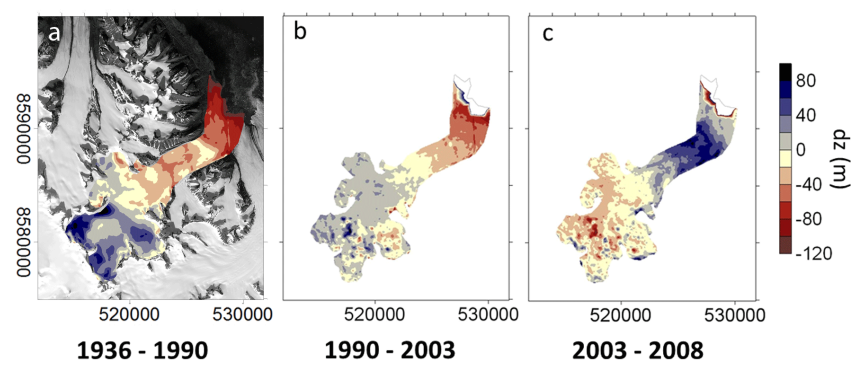

Fig. 3. Surface elevation changes on Zawadzkibreen flowing from SW to NE. (a) Build-up in the upper part; thinning and retreat in the lower part. (b) Surge stage 1: initial lowering in SE basins. (c) Surge stage 2 at the transition to stage 3: lowering of the entire upper part and aggregated thickening in the lower part. Note that the lowermost terminus has not yet advanced and is still undergoing thinning and retreat, and also that some of the areas with the heaviest accumulation correspond to the areas with initial lowering. Background image by SPOT SPIRIT $2008^{\circledR}$.

\subsubsection{Zawadzkibreen}

Zawadzkibreen extended $8 \mathrm{~km}$ farther in 1936 than in 1990 (NPI map B11 Van Keulenfjorden). In the 1936 aerial photographs (NPI) the glacier surface had crevasse fields and crevassed margins reminiscent of the surface in 2008 before the advance. This indicated that Zawadzkibreen experienced a surge around 1936 which did not lead to terminus advance. Thus the elevation changes (1936-1990) in Fig. 3a cover approximately the entire quiescent period and buildup. During quiescence the glacier thickened by up to $60 \mathrm{~m}$ in the upper basins. The transition zone between build-up and thinning indicated the location of the equilibrium line altitude (ELA) during the period 1936-1990. It spans between 350 and $450 \mathrm{~m}$ a.s.l. and was estimated conservatively as $450 \mathrm{~m}$ a.s.1. (Fig. 3a). The centreline velocities in January 1992 were highest in the area around the ELA (Figs. 2a and 4). The 1992 velocities represent the situation about 10 years prior to the initial observed mass transfer and 15 years prior to initial advance and were used to represent quiescent phase velocities.

Between 1990 and 2003 an initial mass displacement occurred from the uppermost basins. An acceleration (Fig. 4d) caused a maximum of $40 \mathrm{~m}$ of drawdown at $1-3 \mathrm{~km}$. Furthermore $10-20 \mathrm{~m}$ of thickening occurred 3-7 km downglacier, i.e. below the ELA (Fig. 4b), and led to stage 1, representing surge initiation (Fig. 3b). The uppermost areas corresponded to the region with greatest accumulation during quiescence (Fig. 3a). In winter 2000-2001 the highest velocities appeared in the higher basins (Fig. 2b).

By 2007 new crevasse fields had developed in the upper and middle glacier. In September 2008, just before the terminus advance, the surface drawdown included the entire accumulation area. Ice thicknesses in the lower part had increased by up to $70 \mathrm{~m}$, while the thicknesses in the upper part had decreased by $40 \mathrm{~m}$. The displaced ice accumulated as a bulge at the confluence with Nathorstbreen (Fig. 3c). From 2007 to 2008, crevasse fields on Zawadzkibreen became more extensive. Velocities could not be calculated for the upper reaches of the glacier, but an area of increased velocities (Fig. 2c) corresponded to the area of ice thickening, which propagated downglacier. By 2007, the 

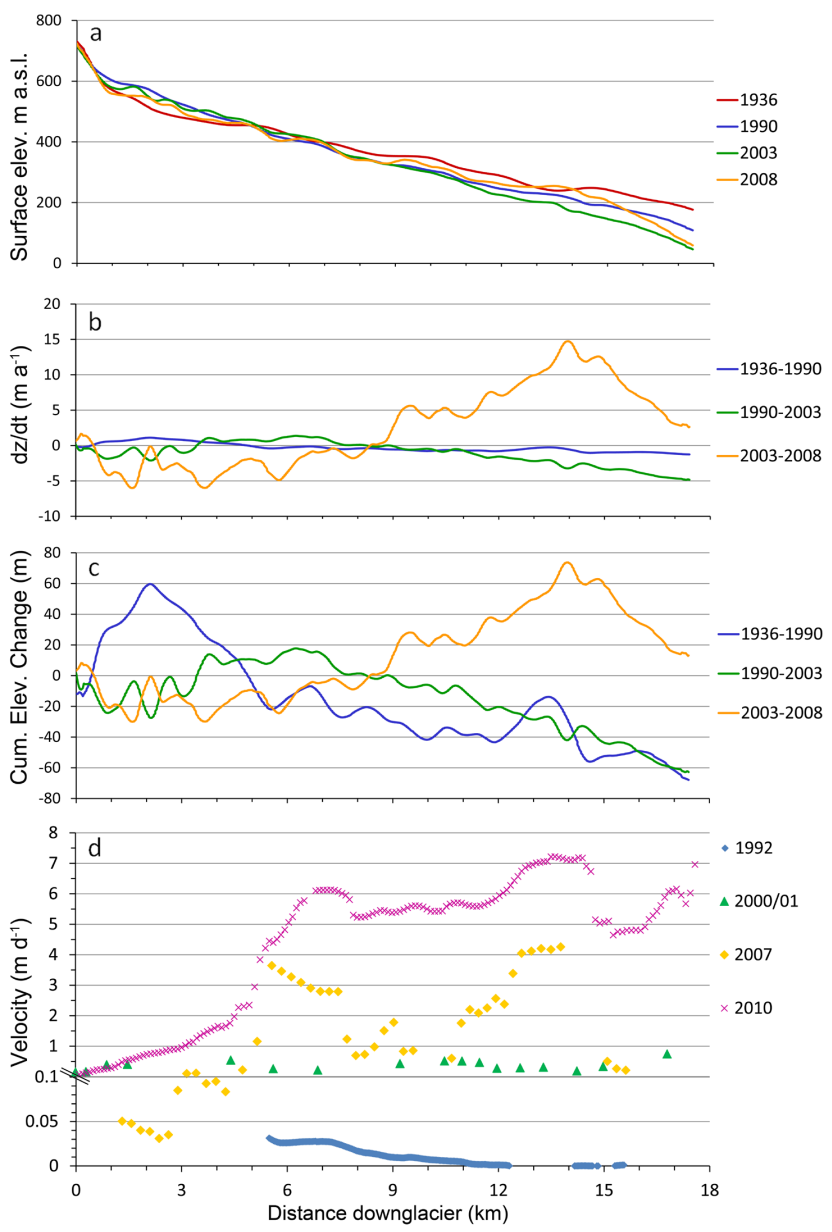

Fig. 4. Zawadzkibreen surface elevation changes along the longitudinal profile from SE to N (location in Fig. 1). (a) Surface elevations during one surge cycle: 1936 to 2008. (b) Annual surface elevation change rate: blue indicates quiescent build-up, green surge stage 1 and orange surge stage 2 (transition to stage 3). Stages 1-3 refer to surge development as described by Sund et al. (2009). (c) Cumulative surface elevation change from previous surge in 1936 towards the transition to stage 3 in 2008. Colours correspond to the surface profile at the end of each interval. (d) Surface velocities from ERS-1 InSAR (1992), ERS-2 (2000-01), Envisat ASAR (2007) and Radarsat-2 (2010) offset-tracking velocities projected onto the profile assuming surface-parallel flow. Note the break in the vertical scale at $0.1 \mathrm{~m} \mathrm{~d}^{-1}$.

velocity increase was several hundred times the velocities in the bulge area in 1992. Four kilometres further downglacier, velocities remained low.

Figure 4 shows changes along the longitudinal profile, starting at the SE basin (Fig. 1). Surface elevation in the upper reaches approached the same levels in 2008 as they were in 1936, at approximately in the same surge stage (Fig. 3a). Although the glacier had been thinning in the lower part, the surface slope below the ELA in 1936 and 1990 (Fig. 4a) was similar, while the slope increased in the upper part in 1990 compared with 1936. The annual change in surface el-

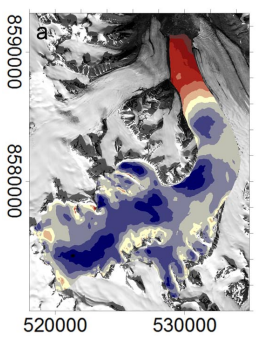

1936 - 1990

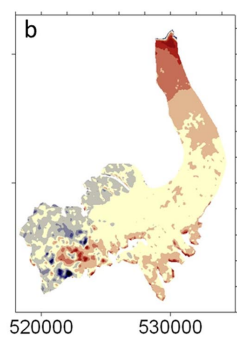

$1990-2003$

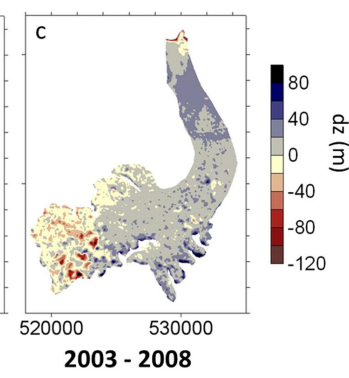

Fig. 5. Surface elevation changes on Polakkbreen flowing from SW to N. (a) Build-up in the upper part; thinning and retreat in the lower part. (b) Surge stage 2: lowering in the southern part of the upper basin. (c) Surge stage 2 at the transition to stage 3: more extensive lowering of the upper part, mass transfer and thickening in the lower part. Note that the lowermost terminus has not yet advanced and still displays thinning and retreat; furthermore some of the areas with the heaviest accumulation correspond to areas with initial lowering. Background image by SPOT SPIRIT $2008^{\circledR}$.

evation (Fig. 4b) shows that during surge stage 1 in the period 1990-2003, the change in mass due to downglacier displacement in the uppermost $3.5 \mathrm{~km}$ was higher than the annual snow accumulation during the quiescent period (19361990). Accounting for the denser ice compared to accumulated snow, the rate of elevation change and mass transfer downglacier during 1990 to 2003 by far exceeded the annual accumulation rate for 1936 to 1990 . This implied an increase in velocity in this area, while aggregation of mass just downglacier (between 3.5 and $8.0 \mathrm{~km}$ ) indicated that velocities had not yet increased in this area. Hence, the glacier is thickening in the area $\sim 2.5 \mathrm{~km}$ downglacier of the ELA (Fig. 4b, c). When the surge had reached late stage 2 by 2008 , just prior to the advance, the uppermost $8.4 \mathrm{~km}$ had lowered, while the lower $\sim 8 \mathrm{~km}$ had risen up to $70 \mathrm{~m}$. Comparison between Fig. $4 \mathrm{~b}$ and $\mathrm{c}$ shows higher mass redistribution rates from stage 1 (1990-2003) to stage 2 (2003-2008) as well as a velocity pattern consistent with the pattern of elevation change (Fig. 4d). By 1992 velocities were highest in the upper part, yet no more than $0.03 \mathrm{~m} \mathrm{~d}^{-1}$. When stage 1 began around 2001, velocities were about $0.15 \mathrm{~m} \mathrm{~d}^{-1}$ in the uppermost reaches, while the area of thickening, between $\sim 4$ and $11 \mathrm{~km}$, shows velocities up to $0.54 \mathrm{~m} \mathrm{~d}^{-1}$. Towards the terminus, velocities were somewhat lower, at $>0.25 \mathrm{~m} \mathrm{~d}^{-1}$. In 2007, 1 year before surge advance, the velocities increased with a more mixed pattern. The highest velocities of more than $4 \mathrm{~m} \mathrm{~d}^{-1}$ were found at $12-13 \mathrm{~km}$, corresponding to the maximum $>7 \mathrm{~m} \mathrm{~d}^{-1}$, almost twice as high as in 2007 and had apparently spread up-glacier (Fig. 4d). Table 1 lists the maximum velocities in the different stages for each glacier and for the joint glacier front. 
Table 1. Velocities during surge development. The highest observed velocities $\left(\mathrm{m} \mathrm{d}^{-1}\right)$ for each period at the different glaciers. The NGS front started to advance after October 2008 (stage 3).

\begin{tabular}{lccccc}
\hline Year/glacier & Dobrowolskibreen & Zawadzkibreen & Polakkbreen & Nathorstbreen & NGS front \\
\hline 1950 & - & - & - & - & 0.2 \\
1992 & 0.014 & 0.03 & 0.043 & - & - \\
$2000 / 2001$ & 0.98 & 0.54 & 0.80 & $<1$ & - \\
2007 & 2.7 & 4 & - & $1.2-1.9$ & $(0.05-0.2)$ \\
$2008 / 2009$ & - & - & - & 9 & $15-20$ \\
2009 & - & - & - & 15 & 25 \\
July 2010 & 6.1 & 5.8 & 4.5 & 6.1 & 12.9 \\
\hline
\end{tabular}

\subsubsection{Polakkbreen}

From 1936 to 1990 Polakkbreen thickened by up to $80 \mathrm{~m}$ in its higher elevations, with the greatest increase on the S-SE part. The unchanged area indicates an ELA at $350 \mathrm{~m}$ a.s.1. (Fig. 5a). The area with the largest accumulation during quiescence corresponds to the zone where a substantial drawdown of up to $60 \mathrm{~m}$ was found for the period 1990-2003 (Fig. 5b). A strong surface gradient between thinning and thickening is present in the lower part (Fig. 5a) and corresponds to a slightly curved medial moraine downglacier of the confluence with Nathorstbreen, apparent on the 1990 NPI aerial photographs. This moraine pattern is not present on the 1936 aerial photographs. During a visit in 1994 (MS) the Polakkbreen part of the terminus appeared the most active of the branches, although still limited. The highest measured speeds on Polakkbreen in January 1992 were located along the centreline in the ELA region. Velocities increased steadily upglacier from the confluence area (Fig. 2a).

On ASTER images from 2003 there are no crevasses visible. Neither Polakkbreen nor Nathorstbreen had a clearly visible bulge prior to or during advance, but nevertheless an undulating surface developed. Between 2003 and 2008 the uppermost part of Polakkbreen thinned by $10-20 \mathrm{~m}$, while the lowermost reaches thickened by $\sim 25 \mathrm{~m}$ (Fig. $5 \mathrm{c}$ ). By winter 2000 a region in the upper basin had an increase in velocities of about 50 times the speeds in this area in 1992 (Fig. 2a, b). Downglacier, velocities were substantially lower.

In 2008, only limited crevasse fields had developed on Polakkbreen and Nathorstbreen-Ljosfonn, though more than were visible in aerial photographs from 1961 and 1990 (NPI). Accompanying the advance during stage 3, substantial crevassing appeared in the lower portion of the NGS. By the end of March 2009 as the terminus advanced, crevasses had spread up-glacier past the glacier confluences. By the beginning of September 2009, large crescent crevasses characterised the higher elevations of Polakkbreen.

\subsubsection{Other glaciers in the system}

In winter 2000-2001 an area in the upper part of Ljosfonn shows increased speed (Fig. 2b) compared to 1992 (Fig. 2a).
Detailed study of images prior to 2008 revealed development of marginal crevasses indicating increased flow, especially along the mountain Keipen (Fig. 1). In late 2007, velocities on Ljosfonn in the upper part of NGS were higher than downglacier at the confluence of Polakkbreen, Nathorstbreen and Dobrowolskibreen (Fig. 2c). For the period of October 2008 to March 2009, orthophoto measurements here show an increase to $8 \mathrm{md}^{-1}$. At the beginning of March 2009, drawdown along the northern sides of the mountain Besshø (Fig. 1) could be seen from Ljosfonn, yet the overall glacier surface still appeared smooth. During summer 2009 , crevasses were seen all the way to the upper basins, although they were still limited in the uppermost parts. During the following months crevasses increased in extent and size. Downglacier from the confluence of Nathorstbreen and Dobrowolskibreen, orthophoto velocities were $14 \mathrm{~m} \mathrm{~d}^{-1}$ in winter 2009-2010 (September-February). Using the image estimates in some areas (e.g. Bessh $\varnothing$ ), showed about $50 \mathrm{~m}$ of lowering of the NGS glacier surface in 2012 as a result of the surge.

\subsection{Surge stage 3: advance, frontal velocities and calving of NGS}

Envisat ASAR wide-swath images indicate that the abrupt advance of NGS occurred after October 2008, when the part of Nathorstbreen draining from Ljosfonn increased its velocity at the same time that Zawadzkibreen did. The medial moraines in these two branches were squeezed together and appear on the early images as a looped moraine in front of the more slowly advancing Polakkbreen. Later this moraine loop disappeared due to calving. Velocities in this area, calculated from orthophotos over 5 months (October 2008-March 2009), are $7-8 \mathrm{~m} \mathrm{~d}^{-1}$, an increase by a factor of more than three since 2007. A conservative estimate for the front position changes gave winter velocities of $9 \mathrm{~m} \mathrm{~d}^{-1}$.

As NGS advanced into Van Keulenfjorden in 2009, the glacier front kept its shape and width. This was possibly due to a submarine ridge separating the drainage channel between NGS and Liestølbreen. Between 24 March and 14 May 2009 the front advanced on average $1 \mathrm{~km}$, a mean velocity of $20 \mathrm{~m} \mathrm{~d}^{-1}$. From 24 March to 25 September the glacier 

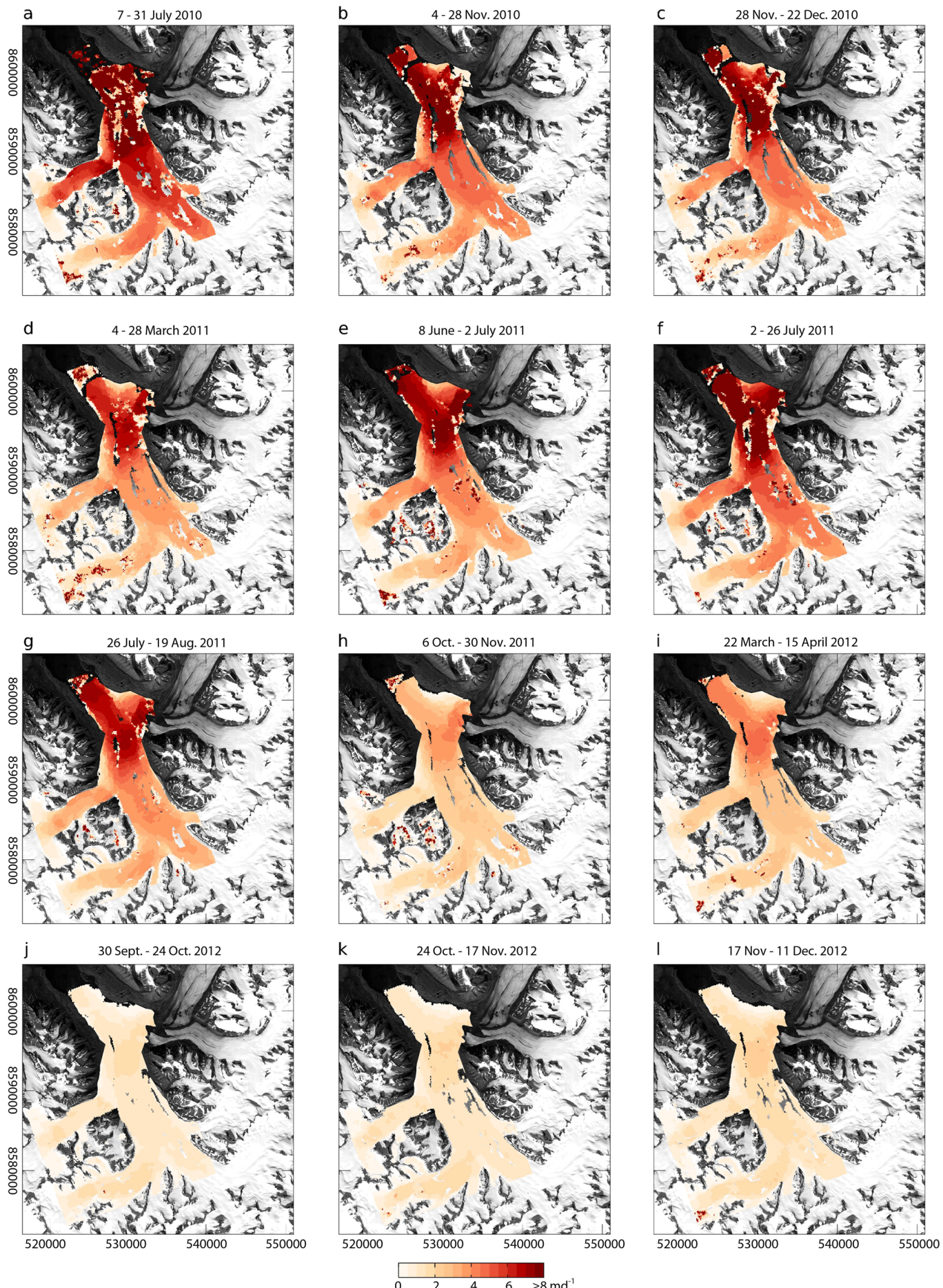

Fig. 6. Surge advance velocity distribution in the different branches of NGS in 2010-2012. Velocities are estimated using offset tracking of 24-day pairs of Radarsat-2 fine-mode SAR data. The border between the glacier terminus and sea ice appears as a black, curved area. Colour scales are enhanced to display velocity variations. Background image by SPOT SPIRIT $2008^{\circledR}$.

advance was $4.5 \mathrm{~km}$ based on the moraine pattern, but the front advanced only $3.5 \mathrm{~km}$, as $1 \mathrm{~km}$ of the glacier length was lost due to calving. In May-September the velocities were approximately $25 \mathrm{~m} \mathrm{~d}^{-1}$.
From 25 September 2009 to 21 February 2010 frontal velocities measured from orthophotos were $14 \mathrm{~m} \mathrm{~d}^{-1}$. The total advance by July 2010 was $\sim 10.4 \mathrm{~km}$, excluding calving but 


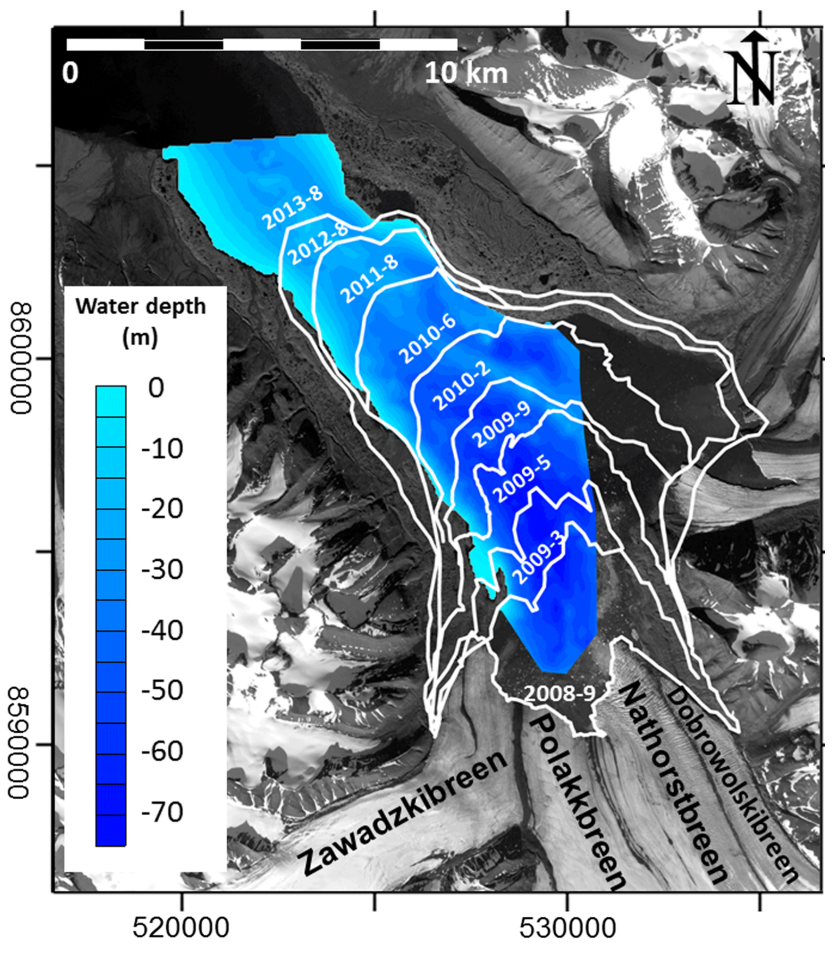

Fig. 7. Front positions (year and month) of Nathorstbreen glacier system during the advancing stage (3) of the surge. Advance by 2013 is $15 \mathrm{~km}$. Bed topography modified from Carlsen (2004). The minimum depth is $11 \mathrm{~m}$, while the maximum depth is $76 \mathrm{~m}$. Background image from 1 September 2008 by SPOT SPIRIT ${ }^{\circledR}$.

including a widening of the terminus into the bay in front of Liestølbreen and Doktorbreen.

Around March-April 2010 the front started to spread out in the bay, causing sea ice up to a distance of $\sim 6 \mathrm{~km}$ from the ice cliff to be pushed. Between the middle and end of July 2010 (Fig. 6a) the frontal $8 \mathrm{~km}$ had almost uniform velocities of $12.9 \mathrm{~m} \mathrm{~d}^{-1}$. Flow rates in the different branches were also rather uniform: Zawadzkibreen at $5.8 \mathrm{~m} \mathrm{~d}^{-1}$, Polakkbreen at $4.5 \mathrm{~m} \mathrm{~d}^{-1}$ and ice flowing from Ljosfonn and Dobrowolskibreen at $6.1 \mathrm{~m} \mathrm{~d}^{-1}$. By October 2010 the inner bay was closed off. Over the following months (Fig. 6b, c) the velocities decreased in all branches and the lowest velocities in the period were in March 2011 (Fig. 6d). From the beginning of June (Fig. 6e) to July 2011 (Fig. 6f) velocities increased in the main trunk. The frontal velocities were about $25 \%$ less than in summer 2010. By August 2011 the NGS had filled the entire inner bay except for two smaller areas damming against Liestølbreen and Doktorbreen. The terminus also continued advancing further out of Van Keulenfjorden. From the end of July to the middle of August 2011 (Fig. 6g) velocities slowed at the front. During October (Fig. 6h) the maximum velocities were reduced even further. For 2010-2012 there were indications of higher velocities generally in summer than in winter.

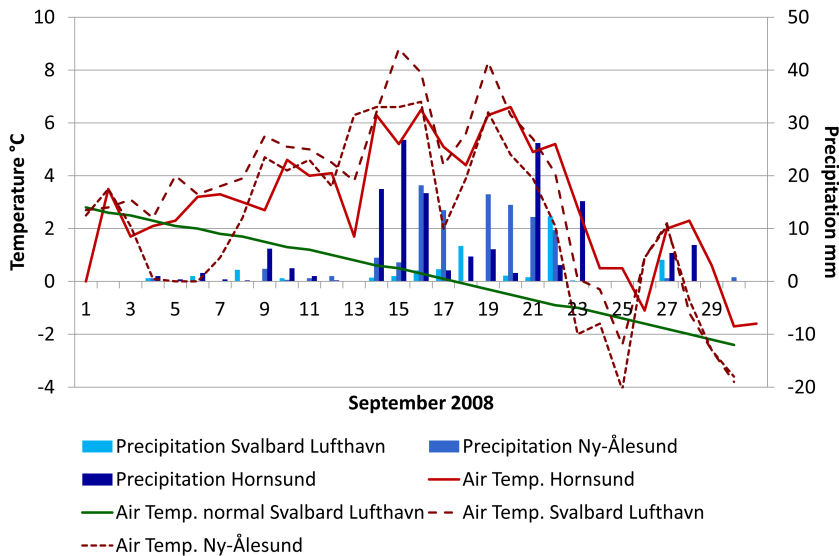

Fig. 8. Daily temperature and precipitation in Ny-Ålesund, Longyearbyen (Svalbard Lufthavn) and Hornsund (location in Fig. 1) in September 2008, immediately prior to surge advance. Data are from the Norwegian Meteorological Institute.

From August 2011 to August 2012 images of NGS show another $1.6 \mathrm{~km}$ advance, indicating average velocities of more than $5 \mathrm{~m} \mathrm{~d}^{-1}$. Between late March and the middle of April 2012 (Fig. 6i) velocities increased slightly compared with October 2011. By autumn 2012, NGS had reached a shallow and narrow part of Van Keulenfjorden and the sea bed in front of the glacier was pushed above the water line. Although some small, new crevasses were observed in the confluence area in August 2012, the overall picture was of slower speeds and crevasse closure, which is in accordance with the velocity pattern in Fig. 6. No SAR data were available between May and September 2012. Frontal velocities for October 2012 (Fig. 6j) are reduced compared with 2011, and from late October, through November 2012 (Fig. 6k) and into December 2012 (Fig. 61), velocities were at the same levels. Compared with the previous winter, flow rates were about only one-third of those in 2011.

Between August 2012 and August 2013 the NGS advanced another $0.9 \mathrm{~km}$. During the whole period of advance the highest velocities coincided with the region covering the deepest part of inner Van Keulenfjorden (Fig. 7). Altogether the NGS has advanced $\sim 15 \mathrm{~km}$, of which some $3 \mathrm{~km}$ along at least $4 \mathrm{~km}$ width of the terminal part of NGS was lost due to calving during the years 2009-2012, amounting to $\sim 12 \mathrm{~km}^{2}$. As a result of the surge NGS increased its area (excluding calving) by $\sim 85 \mathrm{~km}^{2}$ or $20 \%$ to $\sim 515 \mathrm{~km}^{2}$.

\subsection{Hydrometeorological aspects}

There were anomalously high precipitation and temperatures in September 2008. NGS is approximately $40 \mathrm{~km} \mathrm{NE}$ of Hornsund, $100 \mathrm{~km} \mathrm{SSE}$ of Svalbard Lufthavn, close to Longyearbyen and $200 \mathrm{~km}$ SE of Ny-Ålesund (Fig. 1). These locations all are meteorological stations operated by the Norwegian Meteorological Institute, and the data are shown 
in Fig. 8. The 30-year average temperature for Svalbard Lufthavn for September is $0.3{ }^{\circ} \mathrm{C}$ and precipitation is $20 \mathrm{~mm}$. Most days in September 2008 had higher temperatures than average at all stations. Svalbard Lufthavn displays a more continental climate with slightly higher temperatures, and lower precipitation. Even though the two coastal stations $\mathrm{Ny}$ Ålesund and Hornsund are farthest apart they show a similar pattern to each other with anomalously high precipitation for about 10 days. The total 2008 September precipitation in Ny-Ålesund was $99 \mathrm{~mm}$, in Hornsund it was $146 \mathrm{~mm}$ and Svalbard Lufthavn received $36 \mathrm{~mm}$. Based on location as well as precipitation pattern (Hagen et al., 1993), we assumed that precipitation at NGS was more similar to Hornsund than Svalbard Lufthavn.

In both autumn 2009 and 2010, sea ice formed during calm weather when temperatures dropped below $0{ }^{\circ} \mathrm{C}$. We attribute this mainly to freshwater from subglacial drainage and iceberg melt. On clear-weather days, MODIS was used to observe possible turbidity of the water in front of the glaciers. In 2009 and 2010 ice mélange, a mixture of icebergs, ice bits and sea ice, prevented observations of possible turbid water close to the terminus. By the beginning of August 2010 most ice mélange had disappeared and some turbid water was visible in the fjord. During two summer visits in AugustSeptember of these years, no significant amounts of turbid water were observed. A large amount of turbid water in the fjord is visible from MODIS on 18 September 2011. Around 23-24 June 2012 turbid water in the sea in front of the terminus can be observed on several MODIS images, and by the middle of September turbid water is present in almost the entire fjord. Later in October the turbid water is closer to the terminus. This coincides with the period when the glacier advance rate and velocities are substantially reduced. During summer 2013 turbid water was still present in large areas of the fjord. We emphasise that the turbid water observations rely on available images from clear-weather days.

\section{Discussion}

Different surge mechanisms for temperate and polythermal glaciers have previously been suggested (e.g. Murray et al., 2003a). In Svalbard most glaciers are assumed to be polythermal, and temperate conditions are found to prevail in the upper part of the glaciers (e.g. Hagen and Sætrang, 1991; Björnsson et al., 1996; Ødegård et al., 1997; Melvold and Hagen, 1998; Sund and Eiken, 2004). This also applies to NGS, where radio-echo sounding indicates a polythermal regime on Nathorstbreen (Dowdeswell et al., 1984; Fig. 9) and on Ljosfonn (Macheret, 1981). The NGS has experienced the largest surge in Svalbard since 1938 (Fig. 10). Our data enable comparisons of similarities and differences between the NGS and other surge observations, and also suggest a new interpretation of the onset and propagation of surges.

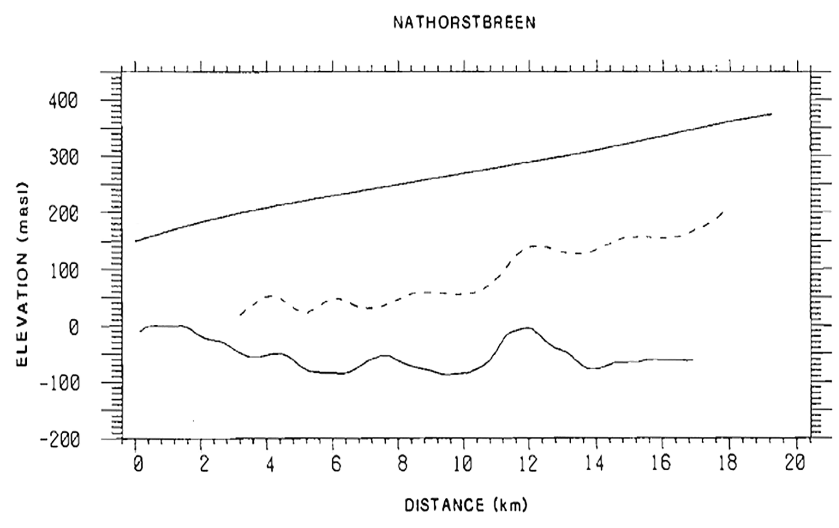

Fig. 9. Radio-echo sounding profile along Nathorstbreen (location in Fig. 1) from Dowdeswell et al. (1984), with permission from the Norwegian Polar Institute. The dashed line indicates the boundary between cold ice (upper) and temperate ice (lower).

\subsection{Surge cycle and build up}

No surges prior to 2008 have been reported for Zawadzkibreen. However, we suggest, based on the appearance of crevasse patterns, that the 1936 surge discussed in this study probably culminated around that time. We interpreted the lack of advance in 1936 to be due to the damming effect of the several-kilometre-long glacier terminus being frozen to the bed. The suggested surge cycle period of ca. 70 years for Zawadzkibreen is also consistent with the $\sim 1870$ advance. A curved medial moraine between Polakkbreen and Nathorstbreen and the sharp gradient between thickening and thinning (Fig. 5a) indicated a period of more extensive flow, possibly due to a partial surge in Polakkbreen between 1936 and 1990. Partial surges are sometimes not clearly identifiable from surface expression (Sund et al., 2009). This points to a more frequent cycle of Polakkbreen than ca. 140 years (1870-2008).

The quiescent phase velocities found for Zawadzkibreen and Polakkbreen (Fig. 2a) are consistent with those observed on other Svalbard surge-type glaciers (e.g. Nuttall et al., 1997; Melvold and Hagen, 1998; Sund and Eiken, 2004). The lowest velocities in these other glaciers occurs in areas where the glacier is frozen to the bed, which suggests that the slow velocities in the lower parts of Zawadzkibreen and Polakkbreen are evidence of predominantly frozen bed conditions.

Our estimate of the Zawadzkibreen ELA was higher than the $350 \mathrm{~m}$ a.s.l. indicated by Hagen et al. (1993), while the ELA of Polakkbreen agreed with their estimate. The difference in ELA between the glaciers is consistent with increasing accumulation rates to the east (Sand et al., 2003). Furthermore, the cirque-shaped basins may provide sheltered conditions with higher accumulation of snow. Accumulation on the lee sides is found on glaciers in central Spitsbergen (Jaedicke and Sandvik, 2002; Eckerstorfer and Christiansen, 2011). 


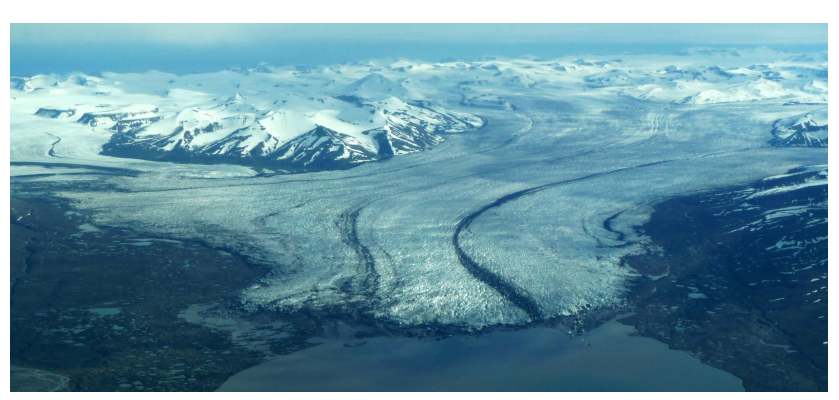

Fig. 10. Nathorstbreen glacier system during surge by 1 August 2012. Photo: SAS/M. Sund.

\subsection{Mass transfer and velocities during surge (stages 1-3)}

The regions of initial lowering on Zawadzkibreen and Polakkbreen (Figs. 3b and 5b) corresponded to the areas where the greatest accumulation was observed (Figs. 3a and 5a). Similar behaviour is observed on Kroppbreen, Svalbard (Sund et al., 2009). On Zawadzkibreen the onset of surface lowering in the upper part was accompanied by increased velocities. Progressive velocity and geometry changes diverging from a normal flow regime are also reported from the upper part of Variegated Glacier (Raymond and Harrison, 1988) and West Fork Glacier, Alaska (Harrison et al., 1994). However, on Zawadzkibreen the transition from a quiescent to a more active phase was more distinct. Mass in the accumulation area was removed faster than it was gained, thus implying that the ice flux past the ELA was greater than the accumulation farther up-glacier, and thus ice flux was larger than balance flux, as defines the surge state. Comparison between Fig. 4a and b shows that by 2003 an initial downglacier thickening, which formed a diffuse surge front at $\sim 9 \mathrm{~km}$, had already occurred in the trunk of Zawadzkibreen. We propose that surge initiation on polythermal glaciers occurs well up in the temperate part and that the downglacier propagation and thickening at the temperate-cold interface subsequently follows.

We suggest the following course for the NGS surge development, spanning several years. An overview of the progress of events is shown in Fig. 11. Areas gaining the largest amount of mass during quiescence will reach enhanced gravitational forcing prior to surrounding areas. In stage 1 this results in locally increased velocity in areas with temperate bed conditions followed by a relative increase in frictional heat at the bed, thus generating more subglacial melt water (Fowler et al., 2001). We assume that englacial water storage is similar to that during quiescence. However, there may be crevasse opening at this stage, allowing more water to penetrate to the bed, thus reinforcing the process. The somewhat higher amount of water available at the bed influences the basal motion (e.g. Iken, 1981; Bartholomaus et al., 2008). A surge nucleus is formed and an initial drawdown occurs and

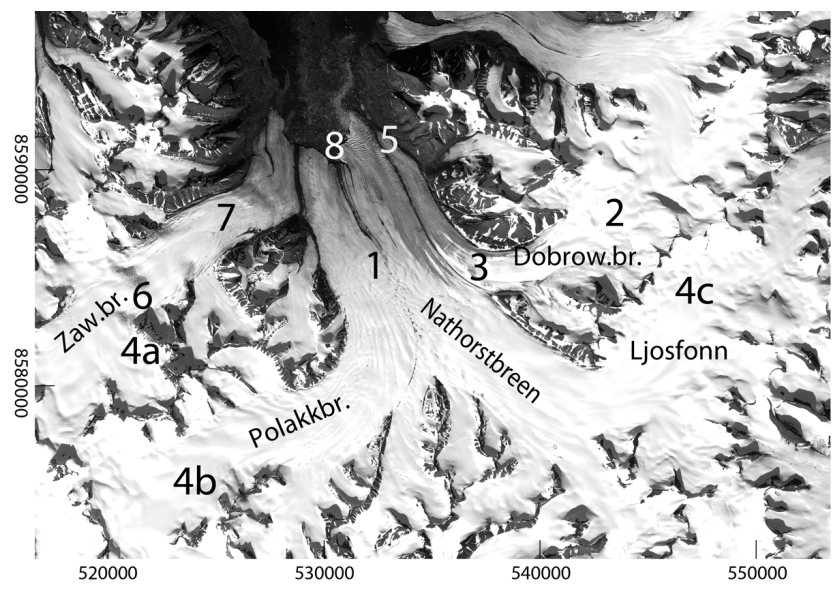

Fig. 11. Progress of surge events in NGS. Events indicated by number and results and discussion references in brackets. Background image by SPOT SPIRIT $2008^{\circledR}$.

1. Curved medial moraine visible by 1990 (4.1.3).

2. Nucleus of increased velocities in Dobrowolskibreen $\sim 1992$ (4.1.1).

3. Downglacier thickening as a part of stage $2 \sim 2003$ (4.1.1).

4a. Zawadzkibreen: initial lowering and increased velocities, stage $1 \sim 2003$ (4.1.2).

4b. Polakkbreen: initial lowering and increased velocities, stage 1 2003 (4.1.3).

4c. Ljosfonn: initial lowering and increased velocities, stage 1 $\sim 2003$ (4.1.4).

5. Dobrowolskibreen: surge has reached the front $\sim 2006$ (4.1.1; 5.3).

6. Zawadzkibreen new crevasses $\sim 2007$ (4.1.2).

7. Zawadzkibreen bulge 2008 (4.1.2; 5.3).

8. NGS: advance, Dobrowolskibreen is accompanied by Zawadzkibreen, Ljosfonn-Nathorstbreen and Polakkbreen $\sim$ winter 2008/2009.

areas immediately downglacier, where velocities have not yet risen, gain more inflow of ice. In stage 2 the local temporary increase in ice thickness, influenced also by higher levels of subglacial meltwater as well as release of englacially stored water from further up-glacier, leads to an amplification of the process. The increased ice flow in additional areas may open new crevasses, further enhancing water flow into the glacier. The above process continues and expands over an increasing area. Positive feedback occurs and the initial surge nucleus propagates downglacier (Budd, 1975; McMeeking and Johnson, 1986). The effect of the frictional heat will be most important when sliding and basal drag are intermediate (Raymond, 2000). A blockage of the subglacial drainage system and change to a distributed drainage system (Robin and Weertman, 1973; Raymond and Harrison, 1985; Kamb, 1987; Eisen et al., 2005) caused by compression between the activated and not-yet-activated ice masses enables the growth of the surge nucleus. Superimposed on this are the seasonal variations where the summer drainage system contracts in 
autumn and traps water which is eventually released (e.g. Lingle and Fatland, 2003). Englacial and subglacial water storage in Svalbard glaciers has, among other, been studied on Scott Turnerbreen, which surged around 1936 (Hodgkins, 1997), and Finsterwalderbreen, as well as being observed on several other glaciers (Nuttall and Hodgkins, 2005). Towards the end of stage 2 or early in stage 3, large amounts of englacial water are released, as described by Lingle and Fatland (2003). At this stage, in addition to sliding, fast flow could also arise from deformation of saturated subglacial sediments, which can accommodate an inefficient drainage system (Clarke et al., 1984; Murray et al., 2000; Harrison and Post, 2003).

\subsection{Glacier surface expressions}

Formation of a bulge at the thermal border between temperate and cold ice has been observed on several glaciers (e.g. Trapridge Glacier, Canada; Clarke et al., 1984). On Zawadzkibreen a visible bulge formed in stage 2 (Fig. 3c) when the activated up-glacier surge nucleus reached what we interpret as a thermal dam. At this stage the situation corresponds to that described on Bakaninbreen, Svalbard (Murray et al., 1998). No distinct bulge appeared on Polakkbreen or Nathorstbreen. We relate the lack of bulge in some branches to differences in individual glacier properties such as the distribution of cold and temperate ice. We suggest that the rate of downglacier thickening here is governed by the temperature conditions of the ice downglacier as well as differences in sliding conditions. Zawadzkibreen probably had substantial cold margins or large areas of cold basal ice, while Ljosfonn - Nathorstbreen was only moderately affected by a cold bed and had a faster propagation of velocity increase (although still moderate) and less change in surface elevation. The termini of tidewater glaciers may slowly start to advance or experience increased calving rates. Radio-echo sounding along the centreline of Nathorstbreen by Dowdeswell et al. (1984) (Figs. 1 and 9) indicated ice thicknesses up to $400 \mathrm{~m}$ and a cold surface layer up to $200 \mathrm{~m}$ thick in the lowermost $18 \mathrm{~km}$ from the terminus position before the surge.

In previous studies, up-glacier propagation of velocities and crevasses has been related to up-glacier propagation of the surge (e.g. Meier and Post, 1969; Hodgkins and Dowdeswell, 1994; Murray et al., 2003b; Pritchard et al., 2005). We suggest a different interpretation. Our results showed that in stage 3, when up-glacier propagation of crevasses occurred, the mass displacement and surge had progressed downglacier for several years. Areas with ice thickness increases and compressive flow during stage 2 subsequently experienced surface lowering and extended flow as the surge propagated further downglacier during stage 3 . At this stage, glacier velocity has reached the highest levels during surge development, leading to a rapid extension of the up-glacier ice. However, the pattern of up-glacier propagation will also depend on the geometric and thermal proper- ties of individual glaciers. Hence the up-glacier propagation of velocities does not represent an up-glacier propagation of the surge from the initiation area but instead a reaction in the last stage of the ice displacement.

Meier and Post (1969) reported that surges in tributary glaciers could trigger surges in the main trunk glacier. We argue that this occurs only if the main trunk is in stage 1 or 2 and is thus ready to reach the final surge stage. When the Dobrowolskibreen surge propagated to the terminus, it possibly "released" the joint terminus of NGS from its frozen northern lateral margin. This did not occur when Skobreen, Svalbard, surged into the main trunk glacier Paulabreen. The latter was not influenced up-glacier (Sund, 2006). No mass displacement took place in (upper) Paulabreen immediately prior to the Skobreen surge, while it had already been through a partial surge about 30 years before. A further example is the surge of Ingerbreen into Richardsbreen, Svalbard. It affected the joint front but did not release any surge in the upper part of Richardsbreen (Sund et al., 2009). However, Medvezhiy Glacier in the Pamir Mountains surged before the calculated critical mass was achieved when the damming ice disappeared (Osipova and Tsvekov, 1991). Our study also shows that glaciers in a system can influence each other by muting the magnitude of surge due to damming effects but can also enhance a surge if their late quiescence and early surge stages coincide.

\subsection{Winter initiation of surges?}

The advance of NGS started during winter 2008-2009 as an abrupt event. It is thus unlike some observations of Svalbard surges (e.g. Murray 2003a, b), while it has similarities to others (Liestøl, 1969; Schytt, 1969). The weather event in September 2008 possibly enhanced the velocity acceleration and hence the timing and force of the advance. At the fast-flowing Kronebreen, close to Ny-Ålesund (Fig. 1), these weather conditions accounted for $15 \%$ of seasonal surface melt, resulting in greater mean velocities in autumn than during summer (Sund, 2011). At Hornsund (Fig. 1), the weather event also caused increased glacier velocities (M. Błaszczyk, personal communication, 2012). Given the common temporal and spatial availability of data for the area a decade or two previously, the abrupt start of the advance of the NGS could easily have been interpreted as an abrupt initiation of the surge. Raymond and Harrison (1985) suggested that the timing of surge initiation in winter coincides with a collapse of the subglacial conduit system due to residual summer meltwater trapped within the glacier. On Monacobreen, Svalbard, velocities more than doubled during winter 1991/1992 (Murray et al., 2003a). Lingle and Fatland (2003) suggested that certain meteorological conditions are necessary to provide large amounts of water for storage in temperate glaciers and are thus a strong contributor to timing of surge onset. By "surge" they referred to behaviour corresponding to stage 3 (Sund et al., 2009). On the one hand, this is consistent with 
observations of the sudden advance of NGS starting in October. On the other hand, we have shown that the advance of NGS surge was just the final stage in a sequence of events. The ongoing mass displacement of NGS had by that time caused some crevassing, enabling water to penetrate into the glacier. Even though the different branches were not at exactly the same surge stage, the September rain event probably expedited the surge development to stage 3 for some branches. Large mass transfers as well as velocity increases for several years prior to advance have been shown in this study. However, the many reported surge advances during winter suggest the importance of changes of the subglacial drainage system during winter in the preceding stages or years prior to surge, as also emphasised by Lingle and Fatland (2003).

\subsection{Front velocities, advance rate and surge termination}

The low retreat rate of NGS during the 6 years prior to the advance due to the surge indicated shallow water in this region. This is supported by the radio-echo profile (Dowdeswell et al., 1984; Fig. 9), which starts at approximately the same location as the 2008 terminus (Fig. 1). Immediately prior to the advance of NGS, the front of the NathorstbreenZawadzkibreen section showed few visible signs of surge behaviour. The situation is comparable to that of Sortebræ, Greenland, where a gradual retreat took place before a rapid switch to advance (Pritchard et al., 2005). Nevertheless, our study proves that retreated front positions are not evidence of contemporary quiescence. The NGS dynamics are consistent with the propagation pattern found on Variegated Glacier (Raymond and Harrison, 1988) and differ from the suggested fast flow initiation in the lower parts of other tidewater glaciers, such as Monacobreen (Murray et al., 2003a, b) and Sortebræ (Pritchard et al., 2005). Interpretation for these two could have been misled by temporal data coverage being too short. If only the period relatively close to the NGS advance is considered, our observations coincide with the latter observations as well.

Velocities between March and May 2009 as well as May and September 2009 based on front displacement are consistent with those measured by Eiken and Sund (2012) for the period March-September, indicating that velocities reached maximum in summer 2009, when the terminus advanced across the deepest part of the bay. The velocities are 100 times greater than front velocities of $\sim 0.2 \mathrm{~m} \mathrm{~d}^{-1}\left(73 \mathrm{~m} \mathrm{a}^{-1}\right)$ measured in the same area in summer 1950, during quiescence (Liestøl, 1977). The flow rates of NGS during surge advance are consistent with those observed from other large surges in Svalbard such as Hinlopenbreen (Liestøl, 1973) and Bråsvellbreen (Schytt, 1969), although the NGS did not entirely reach the levels found at Negribreen (Liestøl, 1969). The NGS velocities are also comparable with velocities in other regions, for example West Fork Glacier, Alaska (Harrison et al., 1994), and Sortebræ, (Pritchard et al., 2005).
In September 2011, September 2012 and summer 2013, large amounts of turbid water were seen in the fjord in front of NGS. In previous studies the existence of turbid water has been related to a collapse of a linked-cavity drainage system (Kamb, 1987) and hence an abrupt end of the surge (Kamb et al., 1985). By 2012 the surge had been active for at least 10 years before flow rates decreased substantially and NGS reached shallow sea bed.

\section{Conclusions}

Using a combination of DEM differencing and various optical and radar remote sensing methods, we have studied the spatial and temporal development of glacier dynamics during the entire surge of the Nathorstbreen glacier system. A previous surge of Zawadzkibreen was found around 1936 and gives a surge cycle of about 70 years, which also corresponds to the period of previously proposed advance of the NGS by 1870.

Areas of maximum accumulation coincided with the surge stage $1(\sim 2003)$ areas of initial lowering, indicating that the initial trigger area was located in the temperate accumulation area of the polythermal glaciers. These regions were also the first to display increased velocities, accelerating to a factor of more than 100 compared with those found during quiescence. Subsequently, in stage $2(\sim 2007)$, mass propagated downglacier with an additional velocity increase of more than 10 times those in stage 1, thus supporting that these initial dynamics are a part of the active surge process. Hence, we hypothesise that surges in Svalbard polythermal glaciers, land-based as well as tidewater-terminating, are initiated high up, in the temperate area.

The suddenness of the surge advance (stage 3 ) initiated in October 2008 was possibly caused by a weather event in September 2008. This also led to surge synchronisation of the different glaciers, which were then at various surge stages. Nevertheless, the surge advance was the final stage in a progression of events with increased velocities and mass displacement occurring over several years. In the first months of advance (stage 3 ) the velocities in the terminal part were 10 times those found during stage 2 . The high temporal and spatial data coverage revealed that on a longer timescale, the surges of the NGS shared characteristics specified for both temperate and polythermal glaciers.

Up-glacier propagation of crevasses occurred mainly in stage 3 as a reaction to increases in velocities after the initial downglacier mass transfer. The different glaciers displayed variations in their surge surface expressions. We relate this to differences in their thermal regime and geometry. The propagation and development of the surge takes different forms depending on the extent of cold marginal and frontal ice. In order to reveal the entire mechanism behind the surge phenomenon it may be necessary to reconsider the study focus. Attention must be paid to the initial stages prior to the visible 
surge as a part of the surge process. Detection of limited but important changes relies on sufficient temporal and spatial resolution.

During a 5-year period NGS advanced $\sim 15 \mathrm{~km}$, filling one-third of the fjord. Although the glacier advanced over this period, it was actively calving, losing some $12 \mathrm{~km}^{2}$ of ice. With no calving the front might have advanced an additional $3 \mathrm{~km}$. Surface lowering of $\sim 50 \mathrm{~m}$ was observed in some areas up-glacier and the total NGS area expanded by $20 \%$. Maximum measured velocities of about $25 \mathrm{~m} \mathrm{~d}^{-1}$ were found during summer 2009, constituting more than 2500 times the lowest velocities during late quiescence. Turbid water was observed in the fjord in the last three autumns. The surge flow rates of NGS are consistent with those observed from other large surges in Svalbard as well as in other regions

Acknowledgements. We are grateful to all photographers, especially C. H. von Quillfeldt, S. Jacobsen and Scandinavian Airline System pilots for their help in obtaining photos from commercial aircraft, as well as to I. and M. Eiken for assistance with fieldwork. The work was partly funded by Svalbard Science Forum Arctic Field Grant. SPOT 5 HRS data are courtesy of the Centre national d'études spatiales (French Space Agency) Stereoscopic survey of Polar Ice: Reference Images and Topographies (SPIRIT) programme, all rights reserved. The 1990 DEM is courtesy of the Norwegian Polar Institute and meteorological data are from the Norwegian Meteorological Institute. The ASTER data are courtesy of NASA, Japan's Ministry of Economy, Trade and Industry (METI), and Japan Space Systems (J-spacesystems) and MODIS data are courtesy of NASA. We thank all for kindly providing data.

The ERS-1 and Envisat SAR data were provided by the European Space Agency through proposal AOPOL.4104. Radarsat-2 SAR data and Envisat Wide-Swath data were provided by Kongsberg Satellite Services (KSAT) through an agreement with Norwegian Space Centre. Financial support was provided by the Norwegian Space Centre and by the Research Council of Norway. Their support is gratefully acknowledged. We thank two anonymous reviewers for their comments and suggestions, which substantially helped focus this paper, and we are also grateful to M. Jackson for help with language corrections.

Edited by: E. Larour

\section{References}

Bartholomaus, T. C., Anderson, R., and Anderson, S. P.: Response of glacier basal motion to transient water storage, Nat. Geosci., 1, 33-37, 2008.

Björnsson, H., Gjessing, Y., Hamran, S. -E., Hagen, J. O., Liestøl, O., Pálsson, O., and Erlingsson, B.: The thermal regime of subpolar glaciers mapped by multi-frequency radio-echo sounding, J. Glaciol., 42, 23-32, 1996.

Budd, W. F.: A first simple model for periodically self-surging glaciers, J. Glaciol., 14, 3-21, 1975.

Carlsen, M.: Deglasiasjon av Van Keulenfjorden, Svalbard, de siste 130 år, (in Norwegian: Deglaciation of Van Keulenfjorden, Sval- bard during the last 130 years), MSc. Thesis, University of Oslo, 69 pp., 2004.

Chen, C. W. and Zebker, H. A.: Two-dimensional phase unwrapping with use of stastistical models for cost functions in nonlinear optimization, J. Opt. Soc. Am. A. 18, 338-351, doi:10.1364/JOSAA.18.000338, 2001.

Clarke, G. K. C.: Fast glacier flow: Ice streams, surging and tidewater glaciers, J. Geophys. Res., 92, 8835-8841, 1987.

Clarke, G. K. C., Collings, S. G., and Thompson, D. E.: Flow, thermal structure and subglacial conditions of a surge-type glacier, Can. J. Earth Sci., 21, 232-240, 1984.

Conway, M.: No man's land: a history of Spitsbergen from its discovery in 1596 to the beginning of the scientific exploration of the country, The University Press, Facsimile edition. Damms Antikvariat AS, 1995, 1906.

Cuffey, K. M. and Patterson, W. S. B.: The physics of glaciers, 4th ed., Academic Press, 704 pp., 2010.

Dowdeswell, J. A., Drewry, D. J., Liestøl, O., and Orheim, O.: Airborne radio echo sounding of sub polar glaciers in Spitsbergen, Norsk Polarinstitutt, Skrifter 182, 41 pp., 1984.

Dolgoushin, L. D. and Osipova, G. B.: Glacier surges and the problem of their forecasting, IAHS Publ. 104, 292-304, 1975.

Echelmeyer, K., Butterfield, R., and Cuillard, D.: Some observations on a recent surge of Peters glacier, Alaska, U.S.A., J. Glaciol., 33, 341-345, 1987.

Eckerstorfer, M. and Christiansen, H. H.: Topographical and meteorological control on snow avalanching in the Longyearbyen area, central Svalbard 2006-2009, Geomorphology, 134, 186196, 2011.

Eiken, T. and Sund, M.: Photogrammetric methods applied to Svalbard glaciers: accuracies and challenges. Polar Res., 31, 18671, doi:org/10.3402/polar.v31i0.18671, 2012.

Eisen, O., Harrison, W. D., Raymond, C. F., Echelmeyer, K.A., Bender, G. A., and Gorda, J. L. D.: Variegated Glacier, Alaska, USA.: A century of surges, J. Glaciol. 51 (174), 399-406, 2005.

Fowler, A. C., Murray, T., and Ng, F. S. L.: Thermally controlled glacier surging, J. Glaciol. 47, 527-538, 2001.

Goldstein, R. M., Engelhardt, H., Kamb, B., and Frolich, R. M.: Satellite Radar Interferometry for Monitoring Ice Sheet Motion: Application to an Antarctic Ice Stream, Science, 262 (5139), 1525-1530, 1993.

Gripp, K: Glaciological and geological results of the Hamburg Spitsbergen-expedition of 1927, in: Spitsbergen push moraines, edited by: Van der Meer, J. J. M., Elsevier, Amsterdam, 3-98, 2004. (Developments in Quaternary Sciences 4), 1927.

Hagen, J. O. and Sætrang, A.: Radio-echo soundings of sub-polar glaciers with low-frequency radar, Polar Res. 9, 99-107, 1991.

Hagen, J. O., Liestøl, O., Roland, E., and Jørgensen, T.: Glacier atlas of Svalbard and Jan Mayen, Nor. Polarinst. Medd. 129, Norw. Polar Inst., Oslo, 1993.

Hamberg, A.: Astronomische, photogrammetrische und erdmagnetische arbeiten der von A.G. Nathorst geleiten schwedischen Polarexpedition 1898, Kungliga Svenska VetenskabsAkademiens Handlingar 39, 115-156, The Dunér-Nordenskiöld map from 1861-1864, 1905.

Harlan, W. B.: The Geology of Svalbard, Memoir, Geol. Soc., 17, 521 pp., ISBN 1-897799-93-4, London, 1997.

Harrison, W. D. and Post, A. S.: How much do we really know about glacier surging?, Ann. Glaciol., 36, 1-6, 2003. 
Harrison, W. D., Echelmeyer, K. A., Chacho, E. F., Raymond, C. F., and Benedict, R. J.: The 187-88 surge of West Fork Glacier, Sutsina basin, Alaska, USA., J. Glaciol., 40, 241-254, 1994.

Hodgkins, R.: Glacier hydrology in Svalbard, Norwegian High Arctic, Quat. Sci. Rev., 16, 957-973, 1997.

Hodgkins, R. and Dowdeswell, J. A.: Tectonic processes in Svalbard tide-water glacier surges: evidence from structural geology, J. Glaciol., 40, 553-560, 1994.

Iken, A.: The effect of the subglacial water pressure on the sliding velocity of a glacier in an idealized numerical model, J. Glaciol., 27, 407-421, 1981.

Jaedicke, C. and Sandvik, A. D.: High resolution snow distribution data from complex arctic terrain - a tool for model validation, Nat. Hazard Earth Syst., 2, 147-155, 2002.

Joughin, I., Tulaczyk, S., Fahnestock, M., and Kwok, R.: A MiniSurge on the Ryder Glacier, Greenland, Observed by Satellite Radar Interferometry, Science, 274, 228-230, 1996.

Kamb, B.: Glacier surge mechanism based on linked cavity configuration of the basal water conduit system, J. Geophys. Res., 92, 9083-9100, 1987.

Kamb, B., Raymond, C. F., Harrison, W. D., Engelhardt, H., Echelmeyer, K. A., Humphrey, N., Brugman, M. M., and Pfeffer, T.: Glacier surge mechanism; 1982-1983 surge of Variegated Glacier, Alaska, Science, 227, 469-479, 1985.

Kääb, A.: Glacier volume changes using ASTER satellite stereo and ICESat GLAS laser altimetry. A test study on Edgeøya, Eastern Svalbard, IEEE Trans. Geosci. Remote Sens., 46, 2823-2830, 2008.

Korona, J., Berthier, E., Bernard, M., Rémy, F., and Thouvenot, E.: SPIRIT. SPOT 5 stereoscopic survey of Polar ice: Reference images and topographies during the Fourth International Polar Year (2007-2009), ISPRS J. Photogramm. Rem. Sens. 64, 2823-2830. doi:10.1016/j.isprsjprs.2008.10.005, 2009.

Larsen, Y., Engen, G., Lauknes, T. R., Malnes, E., and Høgda, K. A.: A generic differential InSAR processing system with applications to land subsidence and SWE retrieval, Proc. Advances in SAR interferometry from ENVISAT and ERS missions (FRINGE 2005), ESA ESRIN, Frascati, Italy, 28 November-2 December, 2005.

Liestøl, O.: Glacier surges in West-Spitsbergen, Can. J. Earth Sci., 6, 895-897, 1969.

Liestøl, O.: Glaciological work in 1971, Norsk Polarinstitutt Årbok 1971, 71-72, 1973.

Liestøl, O.: Årsmorener foran Nathorstbreen?, (in Norwegian: Annual moraines in front of Nathorstbreen?), Norsk Polarinstitutt Årbok 1976, 361-363, 1977.

Lingle, C. S. and Fatland, D. R.: Does englacial water storage drive temperate glacier surges?, Ann. Glaciol., 36, 14-20, 2003.

Macheret, Yu. Ya.: Forms of glacial relief of Spitsbergen glaciers, Ann. Glaciol., 2. 45-51, 1981.

McMeeking, R. M. and Johnson, R. E.: On the mechanics of surging glaciers, J. Glaciol., 32, 120-132, 1986.

Meier, M. F. and Post, A.: What are glacier surges?, Can. J. Earth Sci., 6, 8907-8917, 1969.

Melvold, K. and Hagen, J. O.: Evolution of a surge-type glacier in its quiescent phase: Kongsvegen, Spitsbergen, 1964-95, J. Glaciol., 44, 394-404, 1998.
Murray, T., Dowdeswell, J. A., Drewry, D. J., and Frearson, I.: Geometric evolution and ice dynamics during a surge of Bakaninbreen, Svalbard, J. Glaciol., 44, 263-272, 1998.

Murray, T., Stuart, G. W., Miller, P. J., Woodward, J., Smith, A. M., Porter, P. R., and Jiskoot, H.: Glacier surge propagation by thermal evolution at the bed, J. Geophys. Res., 105, 13491-13507, 2000.

Murray, T., Strozzi, T., Luckman, A., Jiskoot, H., and Christakos, P.: Is there a single surge mechanism? Contrasts in dynamics between glacier surges in Svalbard and other regions, J. Geophys. Res., 108, 2237, doi:10.1029/2002JB001906, 2003a.

Murray, T., Luckman, A., Strozzi, T., and Nuttall, A.-M.: The initiation of glacier surging at Fridtjovbreen, Svalbard, Ann. Glaciol., 36, 110-116, 2003b.

Murray, T., James, T. D., Macheret, Y. Lavrentiev, I., Glazovsky, A., and Sykes, H.: Geometric changes in a tidewater glacier in Svalbard during its surge cycle, Arct. Antarct. Alp. Res., 44, 359367, 2012.

Nuttall, A.-M. and Hodgkins, R.: Temporal variations in flow velocity at Finsterwalderbreen, a Svalbard surge-type glacier, Ann. Glaciol., 42, 71-76, 2005.

Nuttall, A.-M., Hagen, J. O., and Dowdeswell, J.: Quiescent-phase changes in velocity and geometry of Finsterwalderbreen, a surgetype glacier in Svalbard, Ann. Glaciol., 24, 249-254, 1997.

Osipova, G. B. and Tsvekov, D. G.: Kinematics of the surface of a surging glacier (comparison of the Medvezhiy and Variagated Glaciers). IAHS Publ. 208, 345-357, 1991.

Ødegård, R. S., Hagen, J. O., and Hamran, S.-E.: Comparisons of radio-echo sounding (30-1000 MHz) and highresolution borehole-temperature measurements at Finsterwalderbreen, southern Spitsbergen, Svalbard, Ann. Glaciol., 24, 262267, 1997.

Paul, F., Bolch, T., Kääb, A., Nagler, T., Nuth, C., Scharrer, K., Shepherd, A., Strozzi, T., Ticconi, F., Bhambri, R., Berthier, E., Bevan, S., Gourmelen, N., Heid, T., Jeong, S., Kunz, M., Lauknes, T. R., Luckmann, A., Merryman, J., Moholdt, G., Muir, A., Neelmeijer, J., Rankl, M., Van Looy, J., and Van Niel, T.: The Glaciers Climate Change Initiative: Methods for creating glacier area, elevation change and velocity products, Remote Sens. Environ., in press, doi:10.1016/j.rse.2013.07.043, 2013.

Pritchard, H. D., Murray, T., Luckman, A., Strozzi, T., and Barr, S.: Glacier surge dynamics of Sortebræ, east Greenland, from synthetic aperture radar feature tracking, J. Geophys. Res., 110, F03005, doi:10.1029/2004JF000233, 2005.

Raymond, C. F.: How do glaciers surge? A review, J. Geophys. Res., 92 (B9), 9121-9134, 1987.

Raymond, C. F.: Energy balance of ice streams, J. Glaciol., 46, 665674, 2000.

Raymond, C. F. and Harrison, W. D.: Winter initiation of surges, International workshop on Hydraulic effects at the glacier bed and related phenomena, Interlaken, Switzerland, 16-19 September 1985, Abstracts, 1985.

Raymond, C. F. and Harrison, W. D.: Evolution of Variegated Glacier, Alaska, USA, prior to its surge, J. Glaciol. 34, 154-169, 1988.

Rignot, E., Mouginot, J., and Scheuchl, B.: Ice flow of the Antarctic ice sheet. Science, 333, 1427-1450, 2011.

Robin, G. de Q. and Weertman, J.: Cyclic surging of glaciers, J. Glaciol., 12, 3-18, 1973. 
Sand, K., Winther, J.-G., Maréchal, D., Bruland, O., and Melvold, K.: Regional variations of snow accumulation on Spitsbergen, Svalbard, 1997-1999, Nord. Hydrol., 34, 17-32, 2003.

Schytt, V.: Some comments on glacier surges in eastern Svalbard, Can. J. Earth. Sci., 6, 867-871, 1969.

Strozzi, T., Luckman, A., Murray, T., Wegmuller, U., and Werner, C. L.: Glacier motion estimation using SAR offset-tracking procedures, Geoscience and Remote Sensing, IEEE Trans., 40, 23842391, doi:10.1109/TGRS.2002.805079, 2002.

Sund, M.: A surge of Skobreen, Svalbard, Pol. Res. 25, 115-122, 2006.

Sund, M.: On the dynamics of surge-type and tidewater glaciers in Svalbard, PhD-thesis. University Centre in Svalbard/ Faculty of Mathematics and Natural Sciences, University of Oslo, UniPub. 1147, 2011, ISSN 1501-7710, 2011.
Sund, M. and Eiken, T.: Quiescent-phase dynamics and surge history of a polythermal glacier: Hessbreen, Svalbard, J. Glaciol., 50, 547-555, 2004.

Sund, M. and Eiken, T.: Recent surges of Blomstrandbreen, Comfortlessbreen and Nathorstbreen, Svalbard, J. Glaciol., 56, 182184, 2010.

Sund, M., Eiken, T., Hagen, J. O., and Kääb, A.: Svalbard surge dynamics derived from geometric changes, Ann. Glaciol., 50, 5060, 2009. 